\title{
The Ideals of Renewal of European Spiritual Movements in the Americas
}

\author{
Maria Cristina Rios ${ }^{1}$ \\ ${ }^{1}$ Playa Pichiligue 119. Col. Reforma Iztaccihuatl, c.p. 08840. Delegación Iztacalco. Ciudad de México, México. \\ Correspondence: Maria Cristina Rios, Playa Pichiligue 119. Col. Reforma Iztaccihuatl, c.p. 08840. Delegación Iztacalco. \\ Ciudad de México, México.
}

Received: October 30, 2018

Accepted: November 15, 2018 Online Published: November 22, 2018

doi:10.11114/ijecs.v1i2.3727

URL: https://doi.org/10.11114/ijecs.v1i2.3727

\begin{abstract}
This article aims at revealing the connections between the ideals of renewal contained in the European devotions of the Late Middle Ages and those of the missionaries during the first wave of the Evangelization of Mexico. Inspired by a variety of spiritual movements aimed at building an indigenous church and centred on upholding the Law of Christ, these missionaries concur with both the reformers of the Brethren of the Common Life and Luther's political philosophy of attaining a perfect communitas. This research focuses on demonstrating how the ideals of spiritual renewal articulated by Franciscan mystics and missionaries in the Americas embraced the same theological sources as those used by Groote, Eckhart and à Kempis in the Late Middle Ages.
\end{abstract}

Keywords: European spiritual movements, reformers, political utopia, missionaries, Alumbrados, Franciscan mystics

\section{Introduction}

This article aims to demonstrate links between the ideals of renewal of the followers of the Brethren of Common Life the forerunners of Martin Luther's Christian communitas and the missionaries of the first wave of evangelization in Mexico (1524-1550). Inspired by diverse spiritual trends to build an indigenous Church whose core principles were based on the Law of Christ, these missionaries coincided with the Augustinian monk's political philosophy of a utopia to achieve community justice. Both projects held up moral superiority against the corruption of the Church of the Iberian Peninsula in the case of the Franciscans, and of the Church of Rome in the case of the schismatic Saxon friar.

The topic is significantly relevant to $500^{\text {th }}$ anniversary of the Protestant Reformation of 1517 in Europe, which also coincides with the invasion of the Americas with the arrival of the first conquistadors Diego Velázquez, Juan de Grijalva, Pedro de Alvarado, Francisco Montejo, Bernal Díaz del Castillo and Hernán Cortés (Torquemada, 1975, pp. 22-34), among others to the coasts of Yucatán in Mexico and the Caribbean islands of Hispaniola, Jamaica, Cuba and San Juan. These men were accompanied by the first Dominican and Augustinian friars. Following Enrique Dussel's hypothesis, we identify this historical event as the birth of Modernity and the modern subjectivity of the "I conquered", an Otherness that must first deny the recently discovered "Other", the Amerindian, to affirm itself. ${ }^{1}$

The premise of this research consists of proving the evangelizing links found in the Devotio Moderna, Martin Luther and the first Franciscan mystics who arrived in the New Spain in 1523 and 1524 and later. It specifically focuses on the ideals of spiritual renewal that stemmed from the same theological sources as those of reformers of the Late Middle Ages- the schools of the Brethren of Common Life ${ }^{2}$ and their practical devotional rules. These schools influenced some sixteenth century monks and mystics in Northern Europe, members of the critical intellectual movement of that geopolitical region. Martin Luther, Desiderius Erasmus of Rotterdam, Thomas More and the Flemish monks stand out as part of this group, in addition to Pedro de Gante, a Franciscan ${ }^{3}$ supporter of Erasmian humanism as well as a critic of real inverted

\footnotetext{
${ }^{1}$ Modernity does not arise from the first Discourse on the Method by René Descartes and the Discovery of Subjectivity as the "I think," the concrete subjectivity of thinking and doubting the existence of a world outside it (Dussel, 2009).

2 Also known as the Sisters and Brothers of the Common Life (Van Engen, 2008). On June 15, 1522, Luther admits having gone with John Reinecke to the school of the Nüllbrüder or Brethren of the Common Life (Martín Hernández, 1984).

3 The role of the Franciscans in the Late Middle Ages should be noted, especially in terms of the political philosophical criticism of William of Ockham and his double-edged sword known as Ockham's razor used as a metaphor to separate power into temporal and ecclesiastical. Thus, he criticized the absolutist tyrannies of popes and European monarchs. He was also the forerunner of utheranism and a driving force of the conciliatory movement. He sought to fully limit the power of monarchies (Skinner, 1978, p. 30).
} 
Christianism $^{4}$ and a relative of Carlos $\mathrm{V}$ who was also educated along the lines of the moral rules of this devotional current. This philosophy also reached the king's counsellors: Jiménez de Cisneros and Adrian of Utrecht -the future Pope Adrian VI. Hence, the Crown's attempts to correct the departure from the evangelizing project would arise by sending a Second Audience to rectify the abuses of the first one, with humanist listeners like Bartolomé de las Casas and Vasco de Quiroga, among others.

\section{The Devotio Moderna and the New Spain: Heterodoxy With Regard to Catholic Orthodoxy}

The Devotio Moderna reached the Americas and therefore so did the ideals or political utopias of the perfect community, as well as criticism against a corrupt European Church. It is precisely on these two points where Martin Luther coincides with the Franciscan missionaries.

The providentialist political utopias of these mystics - who were no ordinary monks at all, given their lack of standing in European public opinion and the strong criticism against them by "the spiritual ones" 5 brought about the rejection of the encomenderos $^{6}$ and regular clergy in the New Spain since they posed a threat to economic and political interests by becoming serious obstacles. The Franciscan order would bravely confront them with the alternatives of social organization set out in their "Republics of the Indians", an autonomous policy of judicial self-management, analogous to the positive laws imposed by secular and ecclesiastic authorities. The Franciscans opposed the encomenderos on the political basis of their criticism of natural law and evangelical law as the moral boundary of positive law, which mainly consists of loving one's neighbour based on the vows of charity and poverty as an example of an honest life. This was meant to be the model of behaviour for regular Church members, even the Viceroy and his Councillors.

As an institution in the Indies, the Church opposed any resistance against these ideals due to the control that the clergymen exerted by collecting mandatory tithes from the Indians. Meanwhile, the Franciscans exempted the natives from paying these tithes as they were aware of the serious structural hardship in which the Indians lived, ${ }^{7}$ the systematic exploitation in the mines and slavery in the encomiendas. ${ }^{8}$ As an alternative to the lack of tithes, the community of the Spiritual Ones or the Twelve Apostles materially subsisted on voluntary alms, and made the continuity of the utopian missionary project feasible without depending on that excise or, as a result, on the economic and administrative dominion of the Iberian Church in the New Spain enforced by the Viceroy and his council. In this way, they attained genuine political autonomy, the freedom of self-management of their schools, the content of their teachings and administering the sacraments. The latter posed a striking contrast with the fact that the sacraments did not solely depend on a priest since it was enough for someone from the community to hear confession. The same thing happened with baptism, which was carried out en masse due to the shortage of priests, as well as with administering the Eucharist.

The way the sacrament of confession was given is particularly important because it coincides with Martin Luther's spiritual reforms, which advocated for the absolution of sin to no longer depend on a priest as the proprietor of forgiveness, but for the community of the faithful (the fides) to have access to reconciliation through dialogical democratization. In other words, all members could attentively listen to each other, and thus offer a sense of easing and spiritual catharsis. Meanwhile for the Franciscans, the liberation of the penitent Indian would happen by learning their language and their approach since the dependence on a Spanish interpreter to make the priest's spiritual testimony understandable would

\footnotetext{
4 The term inverted is used to denote a power that no longer fulfills its mission. In this case, we say inverted Christianism because it had lost its meaning: love and service to others; on the contrary, it used people and exploited them.

5 The first Franciscans to arrive in the New Spain were the Flemish mystics Juan Aora, Juan de Tecto and Pedro de Gante, who landed in San Juan de Ulúa, Veracruz, with Hernán Cortés on August 30, 1523. In 1524, they were followed by the missionaries called the spiritual ones, also known as the Twelve Apostles of New Spain. The Franciscan Twelve who arrived with the conquistadors in the Early Modern Era in 1524 were Martín de Valencia, Francisco de Soto, Martín de Coruña, Juan Juárez, Antonio de Ciudad Rodrigo, Toribio de Benavente Motolinía, García de Cisneros, Luis de Fuensalida, Juan de Ribas, Francisco Jiménez, Andrés de Córdoba and Juan de Palos. They were later joined by Jerónimo de Mendieta, Bernardino de Sahagún, Juan de Torquemada and Juan de Zumárraga. It is said that the first twelve Franciscans walked barefoot from San Juan de Ulúa to Mexico City.
}

6 An encomendero was a Spanish colonist in possession of a land grant.

7 Bartolomé de Las Casas would likewise oppose both the Indians' encomiendas, like the Franciscans, and the payment of tithes with even more radically than the missionaries because he came to recognize native forms of government and religious practices. He based his convictions on the interpretation of natural law and of the population through what Mauricio Beuchot identified as analogical hermeneutics (Gutiérrez, 2005; Ruiz Sotelo, 2010).

8 According to Merriam-Webster, an encomienda is an "estate of land and the inhabiting American Indians formerly granted to Spanish colonists or adventurers in America for purposes of tribute and evangelization". 
thwart confessional secrecy and obstruct the intimacy of the soul. ${ }^{9}$

Pedro de Gante gained so much popularity though naturally unwanted that Bishop Montúfar considered him the true bishop of the New Spain. Gante's political project and the later Franciscan missionary utopia, like those of Jerónimo de Mendieta, Bernardino de Sahagún and Juan de Torquemada, failed at the time, but left its legacy on the American Creoles and the foundations of their political emancipation in favour of Republicanism. It is to these missionaries that we owe their exemplary nature and contribution to the educational teaching methods for the community, the ethnography and anthropology, emerging studies at the time with a scientific approach. They were also great contributors to comparative linguistics by launching this study in the region. This would play an important role in the missionaries' work as it was an orderly systematization of an effective method of evangelization.

Although the Franciscan political utopias failed in the sixteenth century, they left behind a critical legacy in the nationalist Creole imaginary that followed. One emblematic case is that of Servando Teresa de Mier in the eighteenth century. Teresa de Mier retook the propositions put forward by Juan de Torquemada ${ }^{10}$ on the apparitions of Our Lady of Guadalupe in the New Spain.

One year after de Gante, Juan de Tecto and Juan de Aora landed - the last two friars would die of hunger and misery on their journey with Hernán Cortes, Friar Martín de Valencia arrived. His mission of Franciscans, the Spiritual Ones or the Twelve Apostles of the Americas, would settle in King Netzahualpilli's palace in Texcoco, where they founded the first convent dedicated to St Anthony of Padua.

\section{The Franciscan Missionaries' Project of Modernity in the New Spain}

The missionary ideals of the Catholic Franciscans, Dominicans and Augustinians in the Americas in the first half of the sixteenth century, as well as the political project of the Franciscan utopia, would not be concerned about any contagion of Lutheranism in the Spanish possessions. They only sought the eradication of idolatry and the evangelization of the Indians, which would continue well into the seventeenth century. The Franciscans were considered a heterodox current. They were Catholic not Protestant reformers even though they agreed with the evangelicals (Lutherans) in terms of implementing ascetic ideals of behaviour and promoting the creation of evangelical literature that was more suitable for the natives as a way of following the fundamental commandment of charity and loving one's neighbour. Despite the radical cultural differences, they saw the Americas as a way to recapture a lost paradise, a modern civilizing and providentialist opportunity. Therefore, the missionaries stressed the Tridentine evangelization trends aimed at implementing an imperial policy and propaganda against Luther.

The connection between these humanist reformers and Martin Luther is mainly established by Pedro de Gante, who had been influenced by thirteenth and fourteenth century unorthodox mystics called the Brethren of the Common Life. While it was not a regular order since they did not live in monasteries, they did have a clear educational project based on the common denominator of practicing a philosophy based on the Gospel and on theological interpretation. This led to the creation of the rules for the life of a good Christian, essential for the renewal of humanity by opposing and repudiating the world, given the corruption and the abuses of the Roman Church.

The missionary utopia would sometimes make use of the Indians' ritual practices and traditions to introduce Catholic doctrine. ${ }^{11}$ This gave way to an unprecedented form, a rich cultural syncretism in terms of the semiotic symbolism of religious imagery, which would in turn have an impact on the aesthetics of music, literature and iconography in sixteenth

\footnotetext{
${ }^{9}$ A religious man in the New Spain was overtaxed with pastoral duties of evangelization and lessons at schools for Indian children. All of this made it difficult for the friars to learn the many native languages and there was little time for said tasks. Hence, interpreters were often used as intermediaries during confessions, making it very uncomfortable for the penitent, who would feel intimidated by the presence of an interpreter.

10 Torquemada's hypothesis claimed that Our Lady of Guadalupe appeared in the Americas to Thomas the Apostle before the arrival of the Spaniards, as borne out in hieroglyphics in Indian stones. This hypothesis also sustained by the Augustinian Friar Antonio de la Calancha, said the Gospel was preached in the Western Indies by St Thomas, before the destruction of the temple of Jerusalem, 72 years after Christ death. Servando Teresa de Mier would take up this argument to prove the illegitimacy of the presence of the Spaniards in these lands: if the excuse was Christianization, the Indians were already Christians (Mier, 1994).

${ }^{11}$ According to Ricard (2013) the evangelization in the New Spain was very complex, not only because of the epidemics, the altitude, the climate and the language. Even friars like Bernardino de Sahagún (who knew the Náhuatl language and wrote Historia General de las cosas de la Nueva España [General History of the Things of New Spain], which took him his whole life at the cost of persecution of the regular clergy, were very careful that the concepts of the Christian God and the sacraments of the Catholic Church had no resemblance to the pronunciation of the names of the Mexica gods to thus avoid associations with the pre-Hispanic gods. However, both Echeverría (2000) and Dussel (1992), claim that religious syncretism was exploited by the friars during the evangelization.
} 
century New Spain.

In this sense, the concern of this first wave of evangelization distanced itself from seeing Luther as a threat. For the missionaries, the most important thing was to catechize the Indians and stamp out their idolatry. The more heterodox friars did seek to syncretize the Mexica gods with Christian saints. But here, the figure of Martin Luther would become a ghost since there was no real confessional enemy to fight against. Even then, it created imagery around this controversial figure with echoes in the symbolic rhetoric of the New Spain from the second half of the sixteenth and seventeenth centuries as this image was associated with the anti-Christ and the figure of a dragon or a serpent.

\section{Pedro de Gante: The Successor of the Brethren of Common Life and the Lutheran Utopia}

The schools of the Brethren of Common Life were founded in the fourteenth century by Gerard Groote, a wealthy bourgeois from Brussels who donated one of his properties for women to set up a school to teach underprivileged youth to read and write. The school accepted both religious and lay people. The only condition was to follow the rules of life the school imposed on its members. They practiced rigorous corporal discipline as a way of life; they were amanuenses before the printing press and devoted themselves to copying, illustrating and circulating manuscripts. They lived off of the sale of these manuscripts and unlike the Franciscans, they did not beg. Moreover, they did not approve of a life dedicated solely to contemplation. They had prayer books and one of their practices was broken sleep, as a means of disciplining the body. As copyists of religious books, they found the model of practical life they were to follow in primitive Christianism. This was reflected in their ascetic life, the vow of poverty and life in community without private property, as well as in controlling passions. Martín Hernández states that:

In addition to their strong spirituality and as a basis and support for it canons and friars devoted themselves to transcribing books and copying the best Bible codes and works of the Holy Fathers, as well as manuals of the Liturgy, missals and breviaries with the greatest of care. In the case of the Bible, they made something similar to a critical and annotated edition of the Vulgata - the nostra or archetypal Bible which Thomas à Kempis copied out by hand. The printing press was not yet known. They also stood out for their educational work and the backing they gave to schools, as well as to the education of the people (Martín Hernández, 1984, p. 88).

This movement was born in Flanders and spread to France where they studied Erasmus, à Kempis and Ignatius of Loyola -the founder of the Jesuit Order and considered the person who made a first attempt at reformation two centuries before Martin Luther. For these friars, self-sacrifice was regarded as a virtue to empty the soul and generate the absolute nihilism needed to receive Christ in a spotless abode. Disrupted sleep strengthened the soul against the bodily pleasures; not sleeping became a form of corporal discipline. Their days began with matins (prayer) at four o'clock in the morning and they stayed awake until nine o'clock at night working on their manuscripts. They were mystics, not monks, who were criticized for having relaxed and deviated from their devotional rules from the Christian goal. These friars also depended on the contemplative life of prayer (Devotio Antigua), on the Scholastics and on scholarship. Unlike the Brethren of Common Life who criticized philosophy as an abstract theory, these friars saw the Christian commandment of love for one's neighbour as an active service through the education of disadvantaged youth.

The central belief animating his teaching, which he may have derived from such earlier fourteenth-century mystics as Meister Eckhart and his pupil Johannes Tauler, was that all the efforts men make to commend themselves to God are merely reflections of a sinful vanity, and thus that the aim of the faithful soul must be to remain passive in its acceptance of God's grace (Skinner, 1978, p. 22).

According to Quentin Skinner in The Foundations of Modern Political Thought, these medieval mystics from northern Europe were the precursors of Lutheranism. They were reformers before the controversially so-called reformers, and they held great influence. This was even seen in the Spanish mystics Ignatius of Loyola, John of the Cross and Teresa of Avila, who were also persecuted by the Spanish Inquisition. The idea of an empty soul and its purification so that the Divine Spirit could dwell in it as its abode, was a common belief among mystics dating from medieval times. As Eckhart states, in order to purify the soul, it was necessary to empty it first:

God does not work alike in all hearts, but according as he finds readiness and receptivity. If in some heart there is this or that, there may be something in the "this" or "that" as a result of which God cannot work unhampered. Hence, if the heart is to find preparedness for the highest of all flights, it must aim at a pure nothing, and in this there is the greatest possibility that can exist (Eckhart, 2000, pp. 115-8; 1996). ${ }^{12}$

This idea of the purification of the soul is an interesting mystical nihilism to free it from any substance. When the soul is full of that something, God cannot dwell or act on it since that existing matter would prevent Him from doing so. In this sense, spiritual exercises help clear the ground for spiritual seeds. Therefore, it was necessary to discipline one's body in

12 Emphasis ours. 
self-denial, an ideal shared by the Flemish Franciscan friars and the Spanish mystics that came later. Meister Eckhart's ideas on the inward man can also be found in Erasmus's Enchiridion (1905) as this book contains moral rules to guide the prince to become an ethical model for his subjects, always revolving around the philosophy of Christ and the way of life of the early Christian communities. Eckhart points out that:

$[\ldots]$ the masters tell us that in every man there are two kinds of men. The first is called the outward man, that is, sensitivity. This man is served by the five senses and yet the outer man operates by the power of the soul. The second man is called the inward man: that is the inmost part of the man [...] a religious man that loves God uses the powers of the soul in the outward man no further than what the five senses require [...] And the inward man does not heed the five senses except insofar as he is their guide and leader. He takes care that they do not apply themselves to their object in a bestial manner [...] God expects every religious man to love him with all the powers of his soul. [...] there are some men who completely dissipate the powers of the soul in the outward man. These are the people [...] who know nothing of the inward man [...] the inward man is quite free from [trials] and immovable (Eckhart, 2000, pp. 131-2; 1996).

This is how the nihilism of the soul in its purification receives God. A soul of this kind is wise; it is a guide to action but for this, denial of this world and its disdain is necessary. This is the asceticism promoted by these mystics and where Martin Luther, Erasmus of Rotterdam and the Franciscan mystics agreed on the imperturbability of Divine nature that only needs itself and does not require men to make sacrifices to be pleased through the vows of poverty and chastity. In fact, they sought monasteries where devotional rules were stricter in order to attain purification within themselves and not as the outward man, who depends on the world and on his sensibility and, as a result, loses the substance of his soul, loses control and is irrational.

The movement of these Brethren of Common Life mystics, like Eckhart, à Kempis, and others in northern Europe, was not yet humanistic, but more of a solipsism, a kind of a soul in solitude that is disengaged from the world. Despite its evident influence on humanists, as well as the similarities between the outward and inward man described by Eckhart in the fourteenth century and Erasmus in the sixteenth century, we will not elaborate on these similarities as they are a subject for future research.

The intention of the medieval mystics is, therefore, individualistic. As advocates of celibacy, their founders were against marriage as it was seen as an obstacle to a true union with Christ. They were Christocentric with the life of the Redeemer as the standard of conduct, but always from the silence of the world. Unlike the Franciscans for whom life was always devoted to works of charity among the poor, they lived on alms. However, there is no question as to their influence on both Franciscans and Lutherans, and even humanists in northern Europe like Erasmus and Thomas More. On this point, Henri Pirenne observed:

St. Francis of Assisi and the Franciscans, all who truly are and who are universal and humane, also characterize the best disciples of the schools of the Brethren of Common Life, as well as those who are true followers of Christ. [The teachings of the brethren] led to practical tendencies. They were not content with knowing, they wanted to act; they did not absolve themselves in the contemplation of divine perfection; they did not forget social needs (Márquez, 2001, p. 12).

Thus, we can say that the sixteenth century was an era of both Catholic and Protestant reformers. There was no sharp separation: "Even after the stabilization brought about by the Peace of Augsburg in 1555 in the Empire and the Edict of Nantes in 1598, contacts between one confession and another were quite frequent" (Martín Hernández, 1984, p. 101).

This takes us back to the reforming branch of the Brethren of Common Life and Pedro de Gante, who was a native of the city of Gante. This city, whose main activity was the manufacture and sale of cloths, was also the birthplace of great artists and craftsmen like the Van Dyck brothers and Rembrandt. In terms of economics, Flanders experienced an important class struggle two centuries before the Industrial Revolution. It is the place where, as in the nineteenth century Marx would say, the "original accumulation of capital" began. It was the great era of mercantilism in which the monarchy granted privileges to the eminent merchants and commerce was seen as a "zero-sum" game. In other words, in the trade relationship between two countries, only the exporter won; there was no trade reciprocity. There was great protectionism on behalf of princes in favour of merchants and against the import of goods from neighbouring countries as it was believed that a country's wealth depended on its accumulation of gold and silver and this could only be achieved through exports. In this scenario, a fierce struggle broke out with the new bourgeoisie of tradesmen and merchants on one side and craft guilds (Pirenne, 1980, pp. 149-59), including painters and scholars, on the other. In addition to this, the increasingly impoverished peasants moved to cities with free labour -in the sense of the lack of property- and laws were enacted in northern Europe against begging and vagabonds. These laws were brutally criticized by More in his first book, Utopia.

At this point in time, we can now understand what the protectionist practices and mercantilism of the era meant for New Spain: a beacon of wealth and political power for the Spanish Crown, Castile and Aragon. 


\section{The Devotio Moderna and the "Alumbrados"13 Spanish Mystics Influenced by Erasmus}

In order to understand how the Devotio Moderna and its reformist ideals reached the New Spain, it is necessary to first examine its influence in Spain through a spiritual movement that was not very systematic or methodical. This was the socalled the "Alumbrado" movement, which came into being in the Late Middle Ages. This current coincides with certain devotional rules pertaining to the Brethren of Common Life. This movement emerged before Luther would publish his 95 Theses in 1517. This doctrine is completely independent of Lutheranism although it does coincide with later Erasmism. The Brethren of Common Life held 48 propositions for reform "before the reform", which resulted in the persecution of the "Alumbrados" under an Inquisitorial edict in Toledo in 1525. The members of this group were prosecuted, tortured and burned at the stake in an auto-da-fé. It also marked the beginning of the ban on reading Erasmus as it was associated with being polluted by Lutheranism.

At the core of its doctrine lay an "internalized Christianity", "a living feeling of grace." It was a form of recollection that also consisted of emptying the soul, as Eckhart said, and presenting it to God for Him to fill it with His grace by means of a passive response: "Recollection is spirituality that flourishes then among the reformed Franciscans of the New Castile. It is a blossoming of mysticism fostered after Cisneros that would find is richest and most nuanced expression in the Third Spiritual Alphabet by Friar Francisco de Osuna" (Bataillon, 2013, p. 167).

The spiritual recollection of the "Alumbrados" looked for God within themselves. Therefore, it was necessary to be completely detached from the world. It was necessary to forsake the thought of what is created and of matter, even of discursive thought itself so the mind could become a desert of ideas. This followed the lines of Eckhart's mysticism regarding the inward man contrasting with the outward man, and Erasmus's twenty devotional rules, especially the fifth one, which constitutes its essence.

The common denominator of all these devotional trends of the Brethren of Common Life, Eckhart, the Spanish "Alumbrados" or Illuminati of the late Middle Ages, the Erasmian and Lutheran evangelists of the sixteenth century and the providentialist millenarianism of the Franciscans who followed Joachim of Fiore ${ }^{14}$ in the sixteenth century was more a criticism of the ceremonies than of devotion or faith. For all of them, only the philosophy of Christ should stand at the centre of doctrines, based on the Gospels as the only law. This led to criticism of the life of monks, to whom an ecclesiastic position was not enough to be an ally of the Philosophia Christi. ${ }^{15}$ In this way, they engaged in the defence of the sola fides without Lutheran radicalism. Another similarity worth mentioning is the attack against Scholasticism, which was more theoretical than practical. These currents were preferred above all Evangelism. Likewise, reading bible translations made for the people, a popularization of the teachings of Christianity as a devotion to a single faith, was more valuable than all the monks' ceremonies and their complicated interpretations of the Bible in Latin. All of this disastrously led them to be accused of paganism simply because they saw an excess of the papacy and the regular clergy in Luther's condemnation.

It is interesting to see how the Franciscan spiritual ones and the Spanish "Alumbrados" focused completely on the coming of the Holy Spirit, in the same way as the early Church awaited it, at the centre of its pietism, in a millenarian or providentialist approach to the renewal of humanity. As Bataillon said:

$[\ldots]$ the last word of contemplation consists in saying that the evocation of the holy Humanity of Christ is not a means of becoming one with Christ. Just as the apostles were held in abeyance by the love of the sacred Humanity, which had to be taken away from them so that they might take wing to greater things, desiring the coming of the Holy Spirit. It is also convenient for those who wish to attain high and pure contemplation to leave the creatures of the sacred Humanity to ascend higher and receive more fully the communication of purely spiritual things [...] It is necessary to disengage the heart [...] for it to empty itself and cast out all that has been bred, so that the Lord alone may dwell within it [...] to ultimately achieve a purification of passions and desires (2013, p. 167-8).

Likewise, Eckhart taught the independence of Christ's humanity: "take notice of the words of Christ, speaking of his

13 According to the Encyclopaedia Britannica, Alumbrado refers to "a follower of a mystical movement in Spain during the sixteenth and seventeenth centuries".

14 During the time or cosmic order of Joachim of Fiore it was thought that there were three cycles or ages. The first was the Age of the Father, which corresponded to the Old Testament, characterized by the law and fear of God. The second was the Age of the Son, which was that of the Church and its dogma. The third was the Age of the Holy Spirit, which was impending arrival and characterized by joy and freedom. This went hand in hand with a new intuitive and symbolic understanding of the Gospels, the end of the walled Church and the founding of new contemplative orders. This spiritual age was the dawn of a new day. The Flemish Franciscans saw the Amerindians as the last gentiles on Earth before the coming of the Holy Spirit (Roob, 2014, p. 77).

15 These doctrines were centered on grace as justification or salvation from sin. 
humanity to his disciples: 'It is expedient for you that I go away from you, for if I go not away, the Holy Spirit cannot come to you.' It was just as if he had said: 'You have taken too much joy in my physical presence, hence the perfect joy of the Holy Spirit cannot be imparted to you.' Therefore, strip yourselves of the images and unite yourselves with the formless Being, for God's spiritual consolation is gentle. Therefore, he will only offer himself to those who despise bodily comfort" (Eckhart, 2000, p. 135; 1996). In this way, knowledge of God is obtained through detachment and worldly nihilism and not through Scholasticism or theological study. It is an episteme through a heart already purified of passions, a soul illuminated or enlightened by theological virtues perfected by the Holy Spirit and the evangelical beatitudes (promises). This is a pious and devotional standpoint of an anti-Scholastic nature and is even critical of it, which provoked animosity from the high clergy. It was also critical of ceremonies, which were of no value without the frame of mind and disposition in the intimacy of the soul in one's bosom.

\section{The Doctrine of the "Alumbrados" or "Quietists" in New Spain}

The doctrine of the "Alumbrados" or "Quietists" was based on the idea of pure contemplation and self-annihilation. According to Julio Jiménez Rueda's research entitled Los heterodoxos en México, these mystics sought self-denial of the ego: "The soul engrossed in the infinite essence, bereft of its personality, reaches a state of perfection that makes it irresponsible of sin" (Jiménez Rueda, 1946, p. 139). According to Jiménez, this idea of annihilation is found in the India of Brahmanism, Nirvana, the Neoplatonism of Alexandria and Gnosticism. ${ }^{16}$ However, we do not consider these the most immediate sources, but a closer one, as mentioned above, is found in the teachings and sermons of Meister Eckhart and the Devotio Moderna. It first reached Spain and then New Spain in the sixteenth century. None of these historians delve deeply into the doctrines of these heterodox and therefore remain as superficial judgments about their gnosis and theological truths. Research is made difficult by the fact that they are occult doctrines and were passed on orally to avoid inquisitorial persecution. We cannot deny the various sources from which the spiritual renewals of the sixteenth century, such as the hermetic philosophies from Egypt and ancient Greece, are tempered. It is known that Cosimo de' Medici ordered Marsilio Ficino to translate the hermetic philosophy of Hermes Trismegistus. In that century, the ideas of the macrocosms and microcosms posed by Ptolemy, those of the neo-Platonics, Gnosticism and Copernicus coexisted.

Jiménez Rueda's bases of interpretation regarding the "Alumbrados" are those of Meléndez y Pelayo. The latter maintains that these mystics justified every act of transgression or sin by being in the highest state of contemplation and ecstasy, which would be absolved, and deem it regrettable from the moral perspective: "everything being pure for the pure, the acts committed during ecstasy and the contemplation of the first monad were innocent even though they may seem sinful" (Jiménez Rueda, 1946, p. 140). We find the interpretation given on these "Alumbrados" superficial. There is a problem in associating these mystics with Brahmanic sources as they are rather influenced by the medieval reformers of Northern Europe, who did not seek to justify transgressing acts but a true mystical union. The source of these "Alumbrados" were the teaching of Eckhart and the Devotio Moderna, which inspire both Martin Luther and Erasmus, as well as the Spaniards St. John of the Cross and Teresa of Avila. Both Meléndez y Pelayo and Jiménez see the tenets of these devotional currents in Alexandrine neo-Platonism. Meléndez y Pelayo does not take note of the influence of the medieval mysticism of the Brethren of Common Life and the bases of the Northern European reformers in the sixteenth century. Jiménez, though, does recognize the Protestant legacy: "The influence of Protestantism that preached the uselessness of works, since faith was the only thing capable of saving the soul; that of the German mystics [...] who preached pantheism and quietism, led to the birth of the sect that stirred [...] Spanish society in the second third of the sixteenth century" $(1946$, p. 141).

Our interpreter refers to the sect of the "Alumbrados" and says that the most notable of these was the Franciscan Juan Valdez and his work Divine Considerations. The trial against these mystics is based on the conservative interpretation given by Meléndez y Pelayo:

If in this way they twisted such upright and delicate spirits like that of the author of the Diálogo de la Lengua [Dialogue of the Language], what would it do to the coarse, savage and ignorant populace, what about the bad, rude, concupiscent and angry friars of the rigors of the order; nuns without vocation, the pious women who act like go-betweens, the soldiers coming from India infested with all kinds of vices (Jiménez Rueda, 1946, p. 141).

Jiménez quotes Meléndez y Pelayo and concurs with his argument, but we consider it inquisitorial and conservative, far from the true intentions of the spiritual reforms advocated by the orders of "Alumbrados" who sought to distance themselves from a Church seen as a corrupt institution. As Alicia Meyer states in her book Lutero en el Paraiso [Luther in Paradise], the Saxon monk never was a real threat in New Spain until well into the seventeenth century and only at the

16 Gnosis means knowledge and a gnostic, passes through various levels of awareness. The first fundamental learning is the good news that the essence of the human being itself is divine in nature: the soul appears like a ray of divine light. The second news, the bad news, refers to the "horror of the situation": that ray is prisoner of dark powers. It is confined in exile of matter, bound in the dungeon of the body; bodily senses deceive him; demonic stars defile and haunt him to prevent his return to the divine homeland (Roob, 2014). 
level of rhetoric and narrative was he decisively opposed. However, it seems that both Meléndez and Jiménez considered him a real enemy. The Inquisition persecuted these "Alumbrados" in Spain, but Jiménez interpreted as follows: "The Inquisition began to draw upon all the "Alumbrados", thus attacking a principle of corruption that threatened more than Protestant propaganda or the continuance of Judaism in Spanish life, because it attacked the people themselves, corrupting them and leading them to the prostitution of simple spirits. Easy prey to superstition and deception" (1946, p. 141).

We find this interpretation exaggerated. It was undoubtedly a secret congregation composed of clergymen and, according to Meléndez, their doctrine was a combination of Lutheranism and fanatical illuminism. They did not believe in the mystery of transubstantiation, that is, the conversion of bread and wine into the body and blood of Christ during the Eucharist. They also rejected the veneration of images and denied the existence of hell.

According to Jiménez Rueda, the "Alumbrados" arrived in New Spain fleeing from the monastic rigors of Jiménez de Cisneros -a councillor of Carlos V of Spain - established in response to the laxity in the monastic orders in the Late Middle Ages, which gave way to the Lutheran Reformation. They fled this rigor and took refuge in the New Spain to be more untroubled and without so much control: "Away from Spain, travellers in the vast newly conquered territories felt independent and free from all coercion" (Jiménez Rueda, 1946, p. 159). According to Meléndez y Pelayo, the doctrinal errors of the "Alumbrados" numbered twelve.

1. Mental prayer as a divine precept was enough without needing other precepts.

2. The servants of God should not do physical labour.

3. The prelate, father or superior is not to be obeyed if he orders anything that obstructs contemplation.

4. The trial and evidence of being in a state of grace and being one with the Holy Spirit is manifested in burning sensations, trembling and fainting. Those who are "perfects" do not need to do "virtuous works".

5. The highest level of perfection is attained when it is possible to see in this type of life the divine essence and the mysteries of the Holy Trinity and when the Holy Spirit directs His chosen ones from within.

6. On reaching this level of perfection, contemplating images and hearing sermons should be avoided, as should being forced to go to Mass when in this state.

7. The person who takes communion with greater Form is more perfect.

8. In the state of perfection and grace, forces are drowned out to leave the soul in quietude, neither in the past or the future thoughts.

9. The intercession of saints is useless.

10. It is only necessary to understand what God understands, which is to Himself, in Himself, and in the things of Himself.

11. Once communicated to the soul in this life, God's image remains there forever at the will of who had it.

12. Rapture is a state of the soul between faith and glory. So, in a state of ecstasy there is no faith because one sees God clearly.

These are the twelve rules of the "Alumbrados", which led to their censure by the Inquisition on March 9, 1623. It seems that these spiritual rules had more success in Seville, mainly among noble and wealthy women. Ignorance was not fertile ground for these doctrines, as Meléndez states in his interpretation of the followers, since they were educated. Why did they follow these doctrines? Certain misgivings arise on learning about their spiritual rules and theological truths through the pens of their censors and not through the written testimony of their practitioners, which are hard to find since it was a hermetic and occult doctrine transmitted orally.

According to Jiménez, Spanish mysticism was not only contemplative, but active. It accepted the doctrine of justification, but faith alone was not enough for man's salvation. Charity and good deeds were also needed. For this historian, New Spain was not an educated society. Texts were reserved for a few theologians who read and wrote in Latin. If we assume this interpretation is true, it is possible to understand the rejection of a theological renewal of an anti-Scholastic nature in Miguel Hidalgo's political ideology two centuries later.

In our opinion of the facts, these restrictions for the Scholastic, viceregal Church to penetrate the theological secrets led to mysticism as a more effective form of communication with God, a vehicle to access knowledge. Asceticism and mysticism would be the logical paths to follow in the face of the obstacles set by the institutionalized Church.

According to these historians, if we take these original sources of the "Alumbrados" as true, a more thorough reinterpretation is needed. This spiritual current considered corporeality and even mental images during meditation an impediment to reach a mystical union. The mind should be blank and the material life of this world should be repudiated; 
they deceive us as the Neoplatonists believed. It was necessary for the divine ray of the soul to return to its heavenly home. For Gnosticism, returning that ray to its spiritual origins, the soul had to go beyond the spheres of the Ptolemaic cosmos. According to Ptolemy's order of the cosmos, Saturn's sphere, the outermost one, corresponded to the filthy vestment of the soul. Since lead is a coarse metal, it was necessary to turn it into spiritual gold. In order to pass through this sphere or circle, it was necessary to traverse the death of the body and the decay of matter, a prerequisite for the transmutation of the soul. To be purified, it must pass through the spheres of Jupiter (zinc), Mars (iron), Venus (copper), Mercury (mercury), the Moon (silver) and the Sun (gold). Gnosis was based on the theory that since different metals corresponded to different stages of maturity or illness of a single raw material on its way toward perfection: gold. To be able to pass through the seven doors of the planetary spirits, one must be in possession of Gnosis, of the knowledge of the practices of astral magic. It is different from the neo-Platonic theories, but not entirely. In Platonic dualism, there was a celestial world inhabited by ideas or immutable essences (topus uranus) that lacked representation or images and the material world of appearances or shadows. As copies, they borrowed their reality from the light emanating from the essences. They were tow irreconcilable extremes and therefore, the Gnostics used a series of archetypes or mediating examples.

These two mystical currents, neo-Platonism and Gnosticism co-existed in the Middle Ages. The first was compatible with the orthodox Church because it respected the hierarchies of the State and the Church. However, Gnosticism did not, which is why it was disputed. The Church thought that with the extermination of the "Cathars" and "Waldensians" in the early thirteenth century and the creation of the Holy Office of the Inquisition, gnostic "heresy" had been definitively eradicated. However, the opposite happened. This Alexandrine tradition was resurrected with the Italian Renaissance. "By order of Cosimo de' Medici, in 1463 Marsilio Ficino, the main representative of the Florentine Platonic Academy, translated a compendium of fourteen Gnostic-Neo-Platonic treatises dating from the first centuries of Christianity. This compendium, which was attributed to Hermes "the thrice great", was known as "Corpus Hermeticum" [Hermetic Corpus]" (Roob, 2014, p. 21).

According to Alexander Roob, the success of the resurgence of this "corpus" in the world of Humanism at the end of the fifteenth and sixteenth centuries is due to the spread of knowledge about the ancient mysteries in the style of the New Testament, in a new Christian spirit of renewal, the secret science of the Jews recovered by Pico de la Mirandola, a friend of Ficino's, that reinforced the belief of a philosopher's stone totally Christian in spirit. Thus, spiritual life in Europe is very complex, but the idea of man's "Corpus Hermeticum" as part of God's creative genius fit perfectly with the idea of the Renaissance man.

After having presented the complexity surrounding the doctrinal origins of the devotions of the "Alumbrados" in the New Spain, it is possible to better understand the Franciscans' reforming political utopias and their primitive methods of evangelization linked to their millennialist ideas, as will be seen below.

\section{The Primitive Evangelical Method of the Franciscan Apostles in the New Spain}

The Franciscan missionaries, who arrived in the New Spain in 1524 with Martín de Valencia as their leader, met with Pedro de Gante, the only survivor of the three friars that came in 1523. The difficulties they faced were idolatry, a lack of communication due to diverse languages, the climate, the altitude of Tenochtitlan and epidemics. In general terms, two methods of evangelization can be observed: the clean slate and providential evangelization.

Regarding the clean slate, the Spanish missionaries did not recognize the legitimacy of Indian governments, their religions or cosmonogies. They condemned the Indians as idolatrous and demonic. They came with the idea that converting Indians was a form of charity because it would eradicate the damnation of their souls. In order to so, it was necessary to make a complete break, in the same way that a field left fallow or cleaned for sowing, and then the seed would fall on productive, fertile soil. In this type of evangelization, the missionaries were very careful to use new words to refer to God, the Pope and the Virgin of Guadalupe. They used entirely innovative names so that the Indians would not have an opportunity to conform them to their ancient gods. They even tried not to resort to miracles or promote celebrations of saints because Indians had many festivities to worship their gods. The evangelists did not intend to camouflage idolatry with an appearance of Christianity.

Many idols and pre-Hispanic temples were destroyed. The Franciscans began to found convents in Texcoco and Tlatelolco where schools for the children of the indigenous nobles were established. Resistance was passive, never active, but no less effective. When the missionaries arrived at the communities, they announced, in one way or another, that they came in the name of the Pope and the King, as representatives of the Trinity, and that any disobedience to the ordinances was equal to opposing the God of Christendom. Hence, they had to renounce their gods and cults, as well as human sacrifices. It is recorded that one of the chiefs of the Indian communities replied that they could not renounce what they had learned from their ancestors, nor could they dismiss their customs overnight. To convince them, the friars argued that their gods had not defended them against the Spanish Conquest, which led to an argument between chiefs and priests. 
The Indians showed certain forms of resistance, including emigration to higher areas in the mountains and mountain ranges, but this would only last eight months or a year at most before their being gathered together at Indian reserves for evangelization and catechism. The method of evasion for the nobles was to send their slaves or servants to the convents dressed in elegant robes to receive catechism in their stead; or, failing that, they sent the youngest son and not the firstborn son or successor so as not to corrupt the latter with Christian teachings. Another no less effective form of resistance was that of dressing Tonantzin like the Virgin of Guadalupe. This was so common that in his General History of the Things of New Spain, Bernardino de Sahagún reported that of all the hermitages dedicated to the Marian cult, the most visited one was the Mount of Tepeyac where the ancient goddess was venerated, even though it was now dedicated to the apparitions of the Virgin of Guadalupe. He suspected idolatrous worship because of the large influx of visitors compared to that of other hermitages dedicated to the Virgin. All these forms of resistance, along with many more examples, demonstrated their effectiveness in proving that evangelization in theory was made out to be pure, like a clean slate, but it was actually cultural syncretism.

The friars' insistence on this method, also known as a total break, was a massive folly. One of its consequences was the rebellion of the Indians in northern Mexico, in which the Chichimecas quite cruelly attacked missionaries in the regions of Zacatecas, Sonora and Sinaloa. This trend would continue with Yaqui Indians in northern Mexico until the Mexican Revolution in the early twentieth century. The method was partly effective because of Spanish military might, without which it would have been impossible to quell an armed Indian uprising.

The attempts to eradicate idolatry and anything that would allow Indians to remember it included the destruction of idols and temples, the prohibition of pagan feasts, and even training children to serve as observers to accuse parents, relatives or neighbours who engaged in suspicious practices that seemed like idolatry. Franciscan friars like Bernardino de Sahagún and Motolinía wanted to shun any analogy between pagan and Christian religious practices, as in the case of baptism, communion and confession which were similarly practiced by Mexicas as part of their cult and rites. However, the missionaries judged these practices as having nothing in common with Church sacraments, but were a "satanic parody" (Ricard, 1966, p. 411).

The missionaries saw assimilation as an obstacle to true religious conversion. However, Motolinía, Sahagún and Torquemada embarked on the task of meticulously studying the pre-Hispanic cultures, their languages, their cosmogony and their rites, in order to effect a much more efficient evangelization. The obsession of the regular clergy provoked persecutions against these Franciscan missionaries, mainly instigated by Bishop Montúfar ${ }^{17}$ who viewed them under suspicion of endorsing paganism, according to Jerónimo de Mendieta in both Franciscan Lives and Ecclesiastical Indian History.

Meanwhile, the providentialist method of evangelization made use of what already existed in the primitive culture, and took part in its semiotic resignification. This is precisely what Bolívar Echeverría interprets as an alternative modernity and calls "baroque ethos", a way of life that takes advantage of what already exists as a semiotic cultural survival strategy. This work will not further explore this idea since it goes beyond the scope and hypothesis of this research.

\section{The Religious Eschatologies of Luther and the Franciscan Millenarianists}

Through an exegesis of Luther's letters and sermons, which filled three-quarters of the written press from 1517 to 1545 , contemporary Lutheran theologians agree in their assertion of Luther's eschatological view of the end times. The reformer predicted an upcoming apocalyptic scenario because of the corruption in the Roman Church. This is seen in his On the Babylonian Captivity of the Church where he criticized the abominable papists. This piece was addressed to Leo X and explained that the accusations were not against his divine person, but against his council of corrupt bishops and archbishops. It is doubtful whether it was genuine admiration for the pope since it is known that Luther commissioned Lucas Cranach and Hans Holbein, among other artists, to make pictures of ecclesiastical authorities and the Church as incarnations of the devil, waste and even an ass.

In the New Spain, Luther was associated with the serpent, a demonic animal in the Bible and was also depicted as a dragon. However, the schismatic monk was made present through rhetoric, as Mayer (2008, pp. 101-11) suggests in Lutero en el paraiso [Luther in Paradise], even though his symbolic presence would not surface in social imaginaries until the early seventeenth century. As stressed before, New Spain was more concerned about eradicating the Indians' idolatry than Lutheran contagion.

We know that before Luther's 95 Theses there were other reformers in the Late Middle Ages. Among the millenarian eschatological visions, there is that of the Flemish Franciscan friars who followed Joachim of Fiore (d.1202) in the fifteenth century. This friar from the Late Middle Ages thought that the history of evangelization was divided into three stages: that of the Father, the Son in the fourteenth century and the Holy Spirit, who would announce the coming of the

17 Former qualifier of the Holy Office in New Spain. 
final judgment to rectify the corruption of Europe in the sixteenth century. These ideals of renewal formed the bases of the Franciscan order, whose foundation lay in the commandments of the writings of the early Church and considered the Amerindians the last gentiles before the final judgment.

The first three Flemish Franciscan apostles, who are said to have walked barefoot from San Juan de Ulúa to the city of Tenochtitlán, went to Texcoco, an allied nation of Cortés's, in a desire to be away from the hustle and bustle of the rebuilding of Mexico City. There, they were received by Ixtlixóchitl at the ancient palace of Netzahualpilli (Márquez, 2001, pp. 18-9; Riva Palacios, 1884, pp. 387-402). ${ }^{18}$ According to historian Joaquín Icazbalceta:

They naturally devoted themselves to learning the Mexican language, for which Friar Pedro showed the happiest of dispositions. Before the year was over, the Franciscan mission arrived with guardian Friar Martín de Valencia. Cortés, Ixtlixóchitl and Father Gante went out to meet them and having given, at their request, the necessary message, they said there the first solemn mass on the day of St. Anthony of Padua on June 13 [1524]. The newly arrived were surprised that despite the Conquest and the presence of the three missionaries idolatry still prevailed, and not even the human sacrifices had ceased. They asked their predecessors what they had been doing. Friar Juan de Tecto responded for everyone: "We are learning the theology that St. Augustine ignored at every point," that is, the Mexican language, indispensable to undertake the conversion of all those people (in Márquez, 2001, p. 20).

The history of the Mesoamerican peoples would be written by Franciscans like Sahagún, Motolinía and Juan de Torquemada. Moreover, it was written in Náhuatl and not in Spanish. This is an interesting popularization of the texts in order to make it accessible to the conquered peoples and a way to preserve memories. This did not mean that the friars wanted to keep the cults considered idolatrous, nor did it mean that they would set aside their colonizing bent in favour of the project to unify the Crown through religion. There was no defined project; it was an involuntary form of memory conservation. Avoiding a total semiotic cultural genocide constituted a phenomenon that from a modern perspective could be called the preservation of the immaterial, of the culture of these peoples whose architecture and political organizations was left in complete ruins. But beneath the debris, strength shone through; mestizaje emerged as a mode of survival and culminated in adopting the dominant ways of the conquerors through religion by retaining a "crypto-Mesoamerican" 19 structure. In other words, under the symbolic attire of the ruling class, they continued to venerate Tonantzin and Huitzilopztli, among other rites. In a semiotic dialectical game, the missionaries also took advantage of Mesoamerican cultural vestiges to reassert the Christianization of New Spain.

\section{Conclusions}

This research allows me to conclude that the Devotio Moderna reached New Spain through Pedro de Gante and the Twelve Apostles of New Spain, mystics and Franciscan missionaries who concurred with the devotional reforms of the Northern European mystics during the Late Middle Ages, such as Meister Eckhart, Thomas à Kempis and in particular the Brethren of Common Life. Erasmus of Rotterdam studied in this religious congregation in his youth while Martin Luther visited one of its founders, John Reinecke, to later devote himself to the systematic study of the Devotio Moderna with close affinities found in his work entitled Theologia Germanica and stayed with these Brethren in Magdeburg from 1496 to 1497. The Brethren also influenced both the Spanish mystics and the Flemish missionaries, particularly Pedro de Gante, cousin to Charles V. We also know that the "Twelve Apostles of New Spain" formed part of a movement -the Spiritual Ones- of a millenarian, apocalyptic and utopian nature in the tradition of Joachim of Fiore. Furthermore, they considered the Amerindians the last gentiles before the coming of the end of the world.

The utopia of creating a New Church like that of the early Church to correct the errors of the Old World, sick with ambition and which had inverted its evangelical mission, was shared by both Franciscan mystics and Martin Luther. The Franciscans saw in the Indians - with their modesty, simplicity, poverty and lack of ambition- the opportunity to achieve an ideal Christianity based on poverty, community property, unity in faith and charity. Was not this what Luther was asking for with his sola fides and his original concept of ecclesia founded on the community of the faithful? Thus, both the German reformer and the Franciscan spiritual ones saw the Church of the Old World locked in a Babylonian Captivity, which was an unmistakable sign of the end of time in eschatological and apocalyptic images, with the ecclesiastical

\footnotetext{
18 Father Olmedo, the first friar to accompany Cortés from his departure in Seville to his arrival to the Caribbean islands, particularly Hispaniola and Cuba in 1504, and then to Texcoco in 1524, recounted the way they were received by their high priest. They fought for an entire month until Cortés sent emissaries to request permission to stay. In the council of elders, they decided to ally themselves with Cortés against the Mexica, after his promising them that they would put an end to the tribute to which Moctezuma had subjected them. 19 "crypto" means a hidenned native religious practice, not notorious due to the danger it signified over their lifes. It was a way of ritual practices beneath catholic signs.
} 
hierarchies enthralled in the idolatry towards gold and mired in the sin of ambition and warfare.

The devotional mystics' political critique of contemporary times, which was shared by the Franciscan mendicant orders in New Spain, made it possible to embed the Franciscans' political utopias in their Republics of the Indians by educating the Amerindians and excluding natives from paying tithes given the structural poverty of Indians in the encomiendas. Likewise, their division into guilds of craftsmen, painters, book copyists, musicians, singers, and so on, was an administrative and educational structure that questioned the clergy and Archbishop Montúfar. It culminated in provoking animosity against the mendicant orders which had relative autonomy as they did not depend on tithes, but on alms.

\section{References}

Bataillon, M. (2013). Iluminismo y Erasmismo. El Enquiridión. Erasmo y España. México: Fondo de Cultura Económica. Dussel, E. (1992). Historia de la Iglesia en América Latina. Mexico: Ediciones Mundo Negro-Esquila Misional.

Dussel, E. (2009). Política de la liberación. Spain: Trotta.

Echeverría, B. (2000). La modernidad de lo barroco. Mexico, ERA.

Eckhart, M. (1996). Meister Eckhart, from Whom God Hid Nothing: Sermons, Writings and Sayings. Boston: Shambhala Publications,

Eckhart, M. (2000). El fruto de la nada. España: Siruela.

Gutiérrez, G. (2005). En busca de los pobres de Jesucristo. Bogotá: Universidad Javeriana.

Jiménez, R. J. (1946). Los heterodoxos en México. Mexico: Imprenta Universitaria.

Márquez, I. (2001). La utopía del Renacimiento en tierras indígenas de América, Pedro de Gante, Vasco de Quiroga y Bernardino de Sahagún. Mexico, Puebla: Benemérita Universidad Autónoma de Puebla.

Martín, H. F. (1984). Alcance cultural de la Reforma: Imprenta, escuela, universidad, lengua. In D. Konieki \& J. M. Almanza-Meñica (Eds.), Martín Lutero, 1483-1983: Jornadas Hispano-Alemanas sobre la personalidad y la obra de Martín Lutero en el V Centenario de su nacimiento. Spain: Instituto Superior de Filosofía de Valladolid.

Mayer, A. (2008) Lutero en el Paraíso. México: IIH-UNAM / Fondo de Cultura Económica.

Mier, S. T. de. (1994). Segunda carta de un americano a un español. Escritos y Memorias. Mexico: UNAM.

Pirenne, H. (1980). Historia económica y social de la Edad Media. México: Fondo de Cultura Económica.

Ricard, R. (1966). The Spiritual Conquest of Mexico: An Essay on the Apostolate and the Evangelizing Methods of the Mendicant Orders in New Spain. Ann Arbor: University of Michigan Library. Retrieved from https://quod.lib.umich.edu/cgi/t/text/text-idx?c=acls;cc=acls;view=toc;idno=heb02786.0001.001

Ricard, R. (2013). La conquista espiritual de América. Mexico: Fondo de Cultura Económica.

Riva, P. V. (1884). Historia antigua y de la Conquista. México a través de los siglos (Vol. 2). Mexico: Editorial Cumbre.

Roob, A. (2014). The Hermenetic Museum, Alchemy \& Mysticism. London: Taschen.

Rotterdam, E. (1905). A Book Called in Latin Enchiridion Militis Christiani and in English The Manual of the Christian Knight, replenished with the most wholesome precepts made by the famous clerk Erasmus of Rotterdam, to which is added a new and marvellous profitable Preface. London: Methuen and Co. In Online Library of Liberty. Retrieved from http://oll.libertyfund.org/titles/erasmus-the-manual-of-a-christian-knight\#toc

Ruiz, S. M. (2010). Crítica a la razón imperial. La filosofia política de Bartolomé de las Casas. Mexico: Siglo XXI editores.

Skinner, Q. (1978). The Foundations of Modern Political Thought: The Age of Reformation (Vol. 2). Cambridge: Cambridge University Press.

Torquemada, J. de. (1975). Monarquía indiana (Vol. 2). Mexico: IIH-UNAM.

Van Engen, J. (2008). Sisters and Brothers of the Common Life. The Devotio Moderna and the World of the Later Middle Ages. Philadelphia: University of Pennsylvania Press.

\section{Copyrights}

Copyright for this article is retained by the author(s), with first publication rights granted to the journal.

This is an open-access article distributed under the terms and conditions of the Creative Commons Attribution license (http://creativecommons.org/licenses/by/4.0/). 